\title{
Land-sea coupling of early Pleistocene glacial cycles in the southern North Sea exhibit dominant Northern Hemisphere forcing
}

\author{
Timme H. Donders ${ }^{1,2}$, Niels A. G. M. van Helmond ${ }^{3}$, Roel Verreussel ${ }^{2}$, Dirk Munsterman ${ }^{4}$, Johan ten Veen ${ }^{4}$, \\ Robert P. Speijer ${ }^{5}$, Johan W. H. Weijers ${ }^{3, a}$, Francesca Sangiorgi ${ }^{3}$, Francien Peterse ${ }^{3}$, Gert-Jan Reichart ${ }^{3,6}$, \\ Jaap S. Sinninghe Damsté ${ }^{3,6}$, Lucas Lourens ${ }^{3}$, Gesa Kuhlmann ${ }^{7}$, and Henk Brinkhuis ${ }^{3,6}$ \\ ${ }^{1}$ Department of Physical Geography, Faculty of Geosciences, Utrecht University, Heidelberglaan 2, \\ 3584 CD, Utrecht, the Netherlands \\ ${ }^{2}$ TNO - Applied Geosciences, Netherlands Organisation of Applied Scientific Research Princetonlaan 6, \\ 3584 CB, Utrecht, the Netherlands \\ ${ }^{3}$ Department of Earth Sciences, Faculty of Geosciences, Utrecht University, Heidelberglaan 2, \\ 3584 CS, Utrecht, the Netherlands \\ ${ }^{4} \mathrm{TNO}$ - Geological Survey of the Netherlands, Netherlands Organisation of Applied Scientific Research, \\ Princetonlaan 6, 3584 CB, Utrecht, the Netherlands \\ ${ }^{5}$ Department of Earth and Environmental Sciences, KU Leuven, 3001 Heverlee, Belgium \\ ${ }^{6}$ NIOZ Royal Netherlands Institute for Sea Research, 1790 AB, Den Burg, Texel, the Netherlands \\ ${ }^{7}$ BGR - Federal Institute for Geosciences and Natural Resources, Geozentrum Hannover, Stilleweg 2, \\ 30655 Hanover, Germany \\ ${ }^{a}$ now at: Shell Global Solutions International B.V., Grasweg 31, 1031 HW, Amsterdam, the Netherlands
}

Correspondence: Timme H. Donders (t.h.donders@uu.nl)

Received: 7 September 2017 - Discussion started: 20 September 2017

Revised: 25 January 2018 - Accepted: 14 February 2018 - Published: 23 March 2018

\begin{abstract}
We assess the disputed phase relations between forcing and climatic response in the early Pleistocene with a spliced Gelasian $(\sim 2.6-1.8 \mathrm{Ma})$ multi-proxy record from the southern North Sea basin. The cored sections couple climate evolution on both land and sea during the intensification of Northern Hemisphere glaciation (NHG) in NW Europe, providing the first well-constrained stratigraphic sequence of the classic terrestrial Praetiglian stage. Terrestrial signals were derived from the Eridanos paleoriver, a major fluvial system that contributed a large amount of freshwater to the northeast Atlantic. Due to its latitudinal position, the Eridanos catchment was likely affected by early Pleistocene NHG, leading to intermittent shutdown and reactivation of river flow and sediment transport. Here we apply organic geochemistry, palynology, carbonate isotope geochemistry, and seismostratigraphy to document both vegetation changes in the Eridanos catchment and regional surface water conditions and relate them to early Pleistocene glacial-interglacial
\end{abstract}

cycles and relative sea level changes. Paleomagnetic and palynological data provide a solid integrated timeframe that ties the obliquity cycles, expressed in the borehole geophysical $\operatorname{logs}$, to Marine Isotope Stages (MIS) 103 to 92, independently confirmed by a local benthic oxygen isotope record. Marine and terrestrial palynological and organic geochemical records provide high-resolution reconstructions of relative terrestrial and sea surface temperature (TT and SST), vegetation, relative sea level, and coastal influence.

During the prominent cold stages MIS 98 and 96, as well as 94 , the record indicates increased non-arboreal vegetation, low SST and TT, and low relative sea level. During the warm stages MIS 99, 97, and 95 we infer increased stratification of the water column together with a higher percentage of arboreal vegetation, high SST, and relative sea level maxima. The early Pleistocene distinct warm-cold alterations are synchronous between land and sea, but lead the relative sea level change by $3000-8000$ years. The record provides ev- 
idence for a dominantly Northern Hemisphere-driven cooling that leads the glacial buildup and varies on the obliquity timescale. Southward migration of Arctic surface water masses during glacials, indicated by cool-water dinoflagellate cyst assemblages, is furthermore relevant for the discussion on the relation between the intensity of the Atlantic meridional overturning circulation and ice sheet growth.

\section{Introduction}

The buildup of extensive Northern Hemisphere (NH) land ice started around 3.6 Ma (Ruddiman et al., 1986; Mudelsee and Raymo, 2005; Ravelo et al., 2004; Ravelo, 2010), with stepwise intensifications between 2.7 and $2.54 \mathrm{Ma}$ ago (e.g., Shackleton and Hall, 1984; Raymo et al., 1989; Haug et al., 2005; Lisiecki and Raymo, 2005; Sosdian and Rosenthal, 2009). In the North Atlantic region the first large-scale early Pleistocene glaciations, Marine Isotope Stages (MIS) 10096, are marked by, for example, appearance of ice-rafted debris and southward shift of the Arctic front (see overviews in Naafs et al., 2013; Hennissen et al., 2015). On land, the glaciations led to faunal turnover (e.g., Lister, 2004; Meloro et al., 2008) and widespread vegetation changes (e.g., Zagwijn, 1992; Hooghiemstra and Ran, 1994; Svenning, 2003; Brigham-Grette et al., 2013). Many hypotheses have been put forward to explain the initiation of these $\mathrm{NH}$ glaciations around the Pliocene-Pleistocene transition interval. Causes include tectonics (Keigwin, 1982; Raymo, 1994; Haug and Tiedemann, 1998; Knies et al., 2014; Poore et al., 2006), orbital forcing dominated by obliquity-paced variability (Hays et al., 1976; Maslin et al., 1998; Raymo et al., 2006), and atmospheric $\mathrm{CO}_{2}$ concentration decline (Pagani et al., 2010; Seki et al., 2010; Bartoli et al., 2011) driven by, for example, changes in ocean stratification that affected the biological pump (Haug et al., 1999). Changes were amplified by NH albedo changes (Lawrence et al., 2010), evaporation feedbacks (Haug et al., 2005), and possibly tropical atmospheric circulation change and breakdown of a permanent El Niño (Ravelo et al., 2004; Brierley and Fedorov, 2010; Etourneau et al., 2010).

Key aspects in this discussion are the phase relations between temperature change on land, in the surface and deep ocean, and ice sheet accretion (expressed through global eustatic sea level lowering) in both the Northern Hemisphere and Southern Hemisphere. According to Raymo et al. (2006), early Pleistocene obliquity forcing dominated global sea level and $\delta^{18} \mathrm{O}_{\text {benthic }}$ because precession-paced changes in the Greenland and Antarctic ice sheets canceled each other out. In this view, climate records independent of sea level variations should display significant variations on precession timescale. Recent tests of this hypothesis indicate that early Pleistocene precession signals are prominent in both Laurentide Ice Sheet meltwater pulses and iceberg-rafted debris of the East Antarctic ice sheet and are decoupled from ma- rine $\delta^{18} \mathrm{O}$ (Patterson et al., 2014; Shakun et al., 2016). Alternatively, variations in the total integrated summer energy, which is obliquity controlled, might be responsible for the dominant obliquity pacing of the early Pleistocene (Huybers, 2011; Tzedakis et al., 2017). The dominance of the obliquity component has been attributed to feedbacks between high-latitude insolation, albedo (sea ice and vegetation), and ocean heat flux (Koenig et al., 2011; Tabor et al., 2014). Sosdian and Rosenthal (2009) suggested that temperature variations, based on benthic foraminifer magnesium / calcium $(\mathrm{Mg} / \mathrm{Ca})$ ratios from the North Atlantic, explain a substantial portion of the global variation in the $\delta^{18} \mathrm{O}_{\text {benthic }}$ signal. Early Pleistocene North Atlantic climate responses were closely phased with $\delta^{18} \mathrm{O}_{\text {benthic }}$ changes, evidenced by dominant $41 \mathrm{kyr}$ variability in North American biomarker dust fluxes at IODP Site U1313 (Naafs et al., 2012), suggesting a strong common NH high-latitude imprint on North Atlantic climate signals (Lawrence et al., 2010). Following this reasoning, glacial buildup should be in phase with decreases in $\mathrm{NH}$ sea surface temperatures (SSTs) and terrestrial temperatures (TTs).

To explicitly test this hypothesis we perform a highresolution multiproxy terrestrial and marine palynological, organic geochemical, and stable isotope study on a marginal marine sediment sequence from the southern North Sea (SNS) during the early Pleistocene " 41 kyr world". We investigate the leads and lags of regional marine vs. terrestrial climatic cooling during MIS 102-92 and assess the local sea level response relative to global patterns from the $\delta^{18} \mathrm{O}_{\text {benthic }}$ stack of Lisiecki and Raymo (2005; LR04). In a dominantly $\mathrm{NH}$-obliquity-driven scenario, we expect the marine and terrestrial temperature proxies to be in phase on obliquity timescales with a short (less than $10 \mathrm{kyr}$ ) lead on sea level variations. In addition, the record can better constrain the signature and timing of the regional continental Praetiglian stage (Van der Vlerk and Florschütz, 1953; Zagwijn, 1960) that is still widely used, although its stratigraphic position and original description are not well defined (Donders et al., 2007; Kemna and Westerhoff, 2007; Meijer et al., 2006).

\section{Geological setting}

During the Neogene the epicontinental North Sea basin was confined by landmasses except towards the northwest, where it opened into the Atlantic domain (Fig. 1) (Bijlsma, 1981; Ziegler, 1990). Water depths in the central part were approximately between 100 and $300 \mathrm{~m}$ as deduced from seismic geometry (Huuse et al., 2001; Overeem et al., 2001). In contrast, the recent North Sea has an average depth between 20 and $50 \mathrm{~m}$ in the south that deepens only towards the shelf edge towards $200 \mathrm{~m}$ in the northwest (e.g., Caston, 1979). From the present-day Baltic region a formidable river system, known as the Eridanos paleoriver, developed and built 


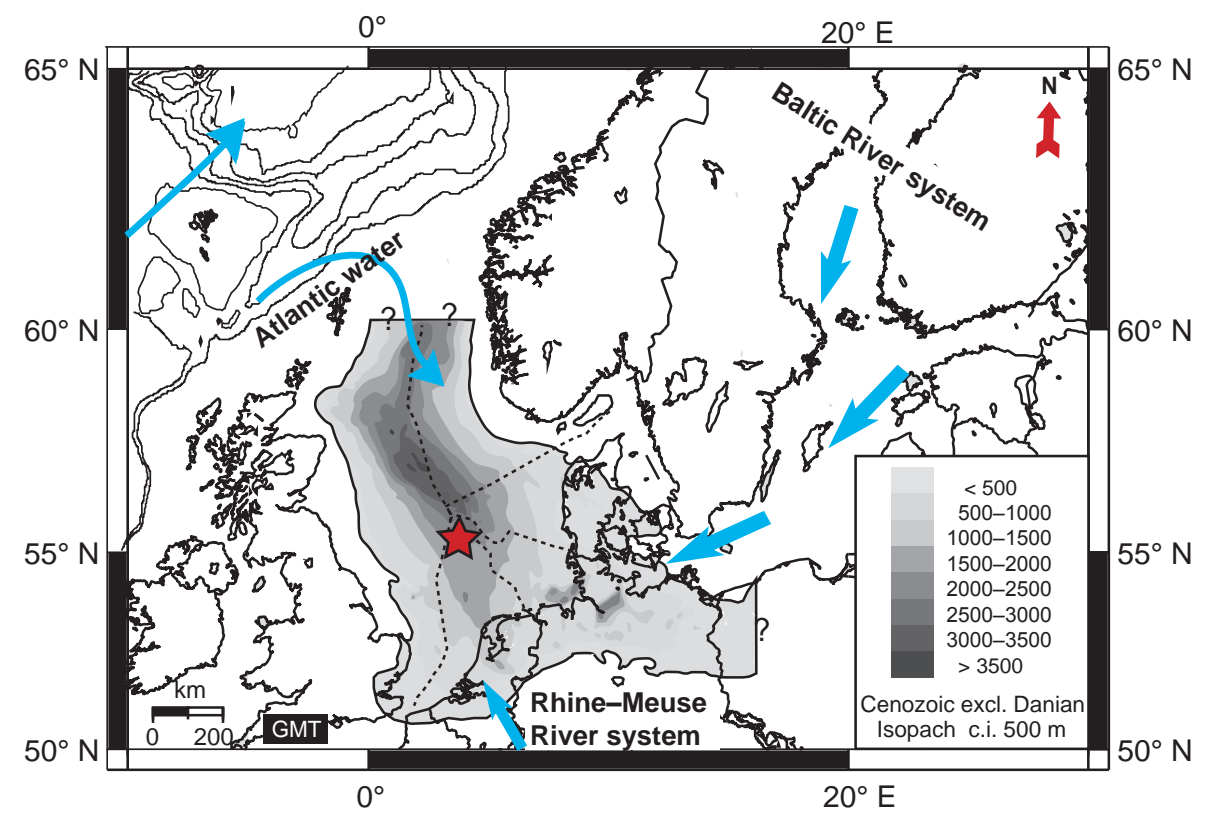

Figure 1. Geographical map of the present-day North Sea region with the superimposed thickness of Cenozoic sediment infill after Ziegler (1990) and the offshore sectors (dashed lines). The reconstructed different water sources (see Gibbard and Lewin, 2016) that influenced the Pliocene and early Pleistocene North Sea hydrography, including the freshwater supply of the Baltic River system, the RhineMeuse River system, and Atlantic surface waters, are indicated with blue arrows. The location of both boreholes A15-3 (UTM X 552567.1, Y 6128751.6) and A15-4 (UTM X 557894.4, Y 6117753.5) is marked by an asterisk; see Fig. S1 in the Supplement for details.

up the southern North Sea delta across southern Scandinavia (Sørensen et al., 1997; Michelsen et al., 1998; Huuse et al., 2001; Overeem et al., 2001).

This delta was characterized by an extensive distributary system that supplied large amounts of freshwater and sediment to the shelf sea during the Neogene and early Pleistocene (Overeem et al., 2001), resulting in a sediment infill of $\sim 1500 \mathrm{~m}$ in the central North Sea Basin (Fig. 1). This system was fed by rainfall as well as by meltwater originating from Scandinavian glaciers (Kuhlmann et al., 2004), principally from the Baltic Shield in the east with some contribution from the south (Fig. 1) (Bijlsma, 1981; Kuhlmann, 2004). The sedimentation rates reached up to $84 \mathrm{~cm} \mathrm{kyr}^{-1}$ at the studied locations (Fig. 2) (Kuhlmann et al., 2006b). Today, the continental river runoff contributes only $0.5 \%$ of the water budget in the North Sea (Zöllmer and Irion, 1996) resulting in sedimentation rates ranging between 0.4 and $1.9 \mathrm{~cm} \mathrm{kyr}^{-1}$ in the Norwegian Channel and between 0.5 and $1 \mathrm{~cm} \mathrm{kyr}^{-1}$ in the southern part of the North Sea (de Haas et al., 1997).

\section{Material, core description, and age model}

Recent exploration efforts in the SNS led to the successful recovery of cored sedimentary successions of MIS 10292 and continuous paleomagnetic logs (Fig. 2) (Kuhlmann et al., 2006a, b). For quantitative palynological and geochemical analyses, discrete sediment samples were taken from two exploration wells, A15-3 and A15-4, located in the northernmost part of the Dutch offshore sector in the SNS at the Neogene sedimentary depocenter (Fig. 1). An integrated age model is available based on a multidisciplinary geochronological analysis of several boreholes within the SNS (Kuhlmann et al., 2006a, b) and dinocyst biostratigraphy. The magnetostratigraphy, core correlation and agediagnostic dinocyst events used for this age model are summarized in Fig. 2 and Table S1 in the Supplement. The recovered material mainly consists of finely grained soft sediments (clayey to very fine sandy), sampled from cuttings, undisturbed sidewall cores, and core sections (Fig. 2). Geochemical analyses were limited to the (sidewall) core intervals, while the cuttings were to increase resolution of the palynological samples, and are based on larger rock chips that have been cleaned before treatment. Clear cyclic variations in the gamma ray signal and associated seismic reflectors across the interval can be correlated across the entire basin (Kuhlmann et al., 2006a; Kuhlmann and Wong, 2008; Thöle et al., 2014). Samples from the two boreholes were spliced based on the gamma-ray logs (Figs. 2, S2 in the Supplement) and biostratigraphic events to generate a composite record. The age model is mainly based on continuous paleomagnetic logging supported by discrete sample measurements and high-resolution biostratigraphy. There is evidence of small hiatuses above $(\sim 2.1 \mathrm{Ma})$ and significant hiatuses below the selected interval (within the early Pliocene and Miocene, particularly the Mid-Miocene Uncon- 


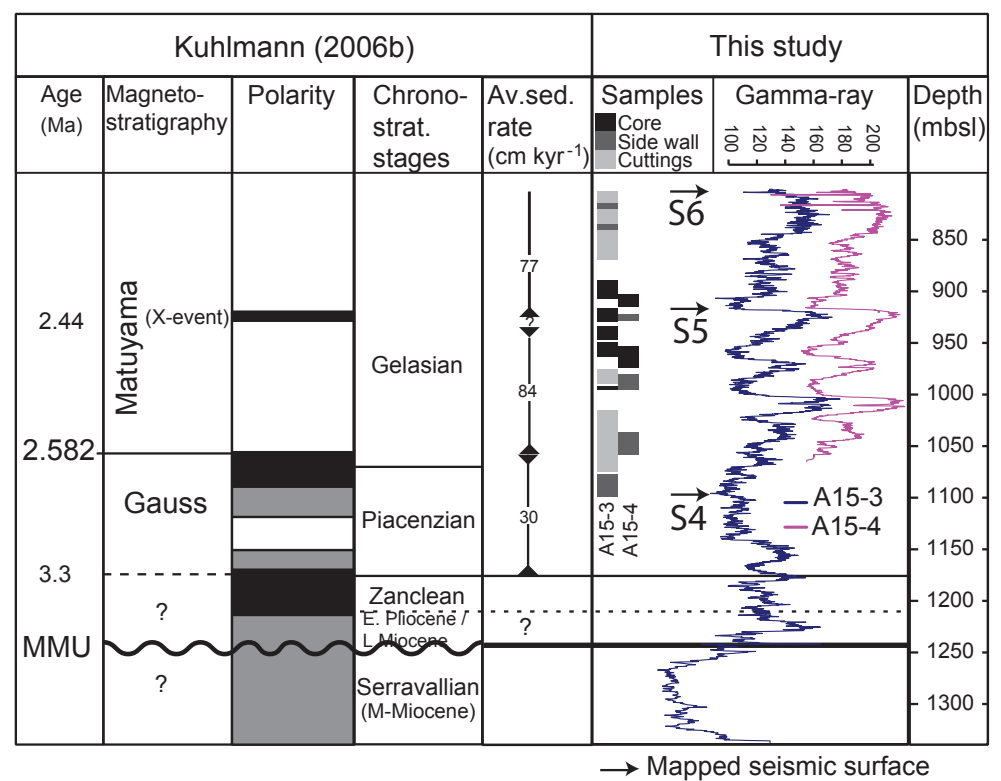

Figure 2. Chronology and mean sedimentation rates as derived from biostratigraphy and paleomagnetic data (Kuhlmann et al., 2006a, b) in combination with the gamma-ray log of A15-3 and A15-4 used in this study on a common depth scale. The position of various sample types and the mapped seismic horizons S4-6 (Fig. S1) are indicated. Material for the sidewall cores is limited and used only for palynology and organic geochemistry. Bioevents based on Kuhlmann et al. (2006a, b) are listed in Table S1.

formity), which is why we excluded these intervals in this study. The position of the Gauss-Matuyama transition at the base of $\log$ unit 6 correlates to the base of MIS 103. The identification of the $\mathrm{X}$ event, at the top of $\log$ unit 9 , correlates to MIS 96, and the Olduvai magnetochron is present within log units 16-18 (Kuhlmann et al., 2006a, b). These ages are supported by dinocyst and several other bioevents (Table S1, updated from Kuhlmann et al., 2006a, b). Consistent with the position of the $\mathrm{X}$ event, the depositional model by Kuhlmann and Wong (2008) relates the relatively coarsely grained, low gamma-ray intervals to interglacials characterized by high runoff. A recent independent study on highresolution stable isotope analyses of benthic foraminifera from an onshore section in the same basin confirmed this phase relation (Noorbergen et al., 2015). Around glacial terminations, when sea level was lower but the basin remained fully marine, massive amounts of very finely grained clayey to fine silty material were deposited in the basin, the waste products of intense glacial erosion. During interglacials with high sea level, more mixed, coarsely grained sediments characterize the deposits, also reflecting a dramatically changed hinterland, retreated glaciers, and possibly (stronger) bottom currents (Kuhlmann and Wong, 2008). Based on this phase relation, detailed magneto- and biostratigraphy, grain size measurements, and previous low-resolution relative SST indices (Kuhlmann et al., 2004; Kuhlmann et al., 2006a, b), the finer-grained units are consistently correlated to MIS 10292. Based on this correlation of the gamma ray inflection points to the corresponding LR04 MIS transitions, the se- quence is here transferred to an age scale through interpolation with a smoothing spline function (Fig. S3 in the Supplement).

The regional structure and development of the delta front across the Pliocene-Pleistocene transition interval is very well constrained by a high-resolution regional geological model that represents the anatomy of the Eridanos (pro-) delta (Kuhlmann and Wong, 2008; Ten Veen et al., 2014). A total of 25 seismic horizons in the Pliocene-Pleistocene transition interval were mapped using a series of publically available 2-D and 3-D seismic surveys across the northern part of the Dutch offshore sector. For all these surfaces the distribution of delta elements such as of topset, foreset, and toeset to prodelta has been determined, resulting in zonal maps $(250 \mathrm{~m}$ grid size) that represent the present-day geometry of the surfaces. The paleoenvironmental reconstructions are compared to these maps to constrain the regional setting and aid the interpretations.

\section{Paleoenvironmental proxies and methods}

\subsection{Benthic oxygen and carbon isotopes $\left(\delta^{18} \mathrm{O}_{\mathrm{b}}\right.$ and $\left.\delta^{13} \mathrm{C}_{\mathrm{b}}\right)$}

Oxygen and carbon isotopes were measured on tests of Cassidulina teretis, a cold-water species of endobenthic foraminifera that is generally abundant in the samples and common in finely grained sediment and at relatively low salinities (Mackensen and Hald, 1988; Rosoff and Corliss, 1992). Because of their endobenthic habitat, they record iso- 
tope compositions of pore waters, which leads to somewhat reduced $\left(\delta^{13} \mathrm{C}_{\mathrm{b}}\right)$ values compared to the overlying bottom waters. Since the amount of material from the sidewall cores is limited, the isotope data are only produced for the cored intervals with the principal aim to confirm the phase relationship described by Kuhlmann and Wong (2008) between facies and climate. Preservation was based on a visual inspection and assignment of a relative preservation scale of $1-5$, after which the poorest two classes were discarded because primary calcite was nearly absent. The best-preserved specimens (cat. 1) had shiny tests (original wall calcite) and showed no signs of overgrowth. Category 2 specimens showed signs of overgrowth but were not recrystallized and cat. 3 specimens were dull and overgrown by a thin layer of secondary calcite. Between $\sim 20$ and $50 \mu \mathrm{g}$ of specimens per sample was weighed, after which the isotopes of the carbonate were measured using a Kiel III device coupled to a 253 Thermo Finnigan MAT instrument. Isotope measurements were normalized to an external standard "NBS-19" $\left(\delta^{18} \mathrm{O}=-2.20 \% o, \delta^{13} \mathrm{C}=1.95 \%\right)$.

\subsection{Palynological proxies}

In modern oceans, dinoflagellates are an important component of the (phyto)plankton. About $15-20 \%$ of the marine dinoflagellates form an organic walled cyst (dinocyst) during the life cycle that can be preserved in sediments (Head, 1996). Dinocyst distribution in marine surface sediments has shown to reflect changes in the sea surface water properties, mostly responding to temperature (e.g., Rochon et al., 1999; Zonneveld et al., 2013). Down-core changes in dinocyst assemblages are widely used in reconstructing past environmental changes in the Quaternary (e.g., de Vernal et al., 2009), but also in the Neogene and Paleogene (e.g., Versteegh and Zonneveld, 1994; Head et al., 2004; Pross and Brinkhuis, 2005; Sluijs et al., 2005; Schreck et al., 2013; De Schepper et al., 2011, 2013; Hennissen et al., 2017).

Here we use the preference of certain taxa for coldtemperate to arctic surface waters to derive SST trends. The cumulative percentage of the dinocysts Filisphaera microornata, Filisphaera filifera, Filisphaera sp., Habibacysta tectata, and Bitectatodinium tepikiense in the total dinocysts represents our cold surface water indicator (Versteegh and Zonneveld, 1994; Donders et al., 2009; De Schepper et al., 2011). Interestingly, Bitectatodinium tepikiense, the only extant dinocyst among our cold-water species, has been recorded from the mixing zone of polar front oceanic waters with cold brackish meltwaters from glacier ice (e.g., Bakken and Dale, 1986) and at the transition between the subpolar and temperate zones (Dale, 1996). The combined abundance of Lingulodinium machaerophorum, Tuberculodinium vancampoae, Polysphaeridium zoharyi, and Operculodinium israelianum is used here to indicate coastal waters, although they generally also relate to warmer conditions. In particular, high percentages of $L$. machaerophorum are typically recorded in eutrophic coastal areas where reduced salinity and (seasonal) stratification due to runoff occur (Dale, 1996; Sangiorgi and Donders, 2004; Zonneveld et al., 2009). At present, $T$. vancampoae, $P$. zoharyi, and $O$. israelianum are also found in lagoonal euryhaline environments (Zonneveld et al., 2013) and hence could be used to indicate a more proximal condition relative to $L$. machaerophorum (Pross and Brinkhuis, 2005).

At present, Protoperidinioid (P) cysts are mostly formed by heterotrophic dinoflagellates and the percentage of $\mathrm{P}$ cysts may be used as an indicator of high eukaryotic productivity (see Reichart and Brinkhuis, 2003; Sangiorgi and Donders, 2004; Sluijs et al., 2005). Here we use the percentage of P cysts (Brigantedinium spp., Lejeunecysta spp., Trinovantedinium glorianum, Selenopemphix spp., Islandinium spp., Barssidinium graminosum, and B. wrennii) to indicate eukaryotic productivity.

Terrestrial palynomorphs (sporomorphs) reflect variations in the vegetation on the surrounding land masses and provide information on climate variables such as continental temperatures and precipitation (e.g., Heusser and Shackleton, 1979; Donders et al., 2009; Kotthoff et al., 2014). A ratio of terrestrial to marine palynomorphs ( $\mathrm{T} / \mathrm{M}$ ratio) is widely used as a relative measure of distance to the coast and thereby reflects sea level variations and depth trends in the basin (e.g., McCarthy and Mudie, 1998; Donders et al., 2009; Quaijtaal et al., 2014; Kotthoff et al., 2014). Morphological characteristics of late Neogene pollen types can, in most cases, be related to extant genera and families (Donders et al., 2009; Larsson et al., 2011; Kotthoff et al., 2014). In A15-3 and A15-4, the relatively long distance between the land and the site of deposition means that the pollen assemblage is not only a reflection of vegetation cover and climate but also includes information on the mode of transport. Assemblages with a relatively high number of taxa, including insect-pollinated forms, are indicative of substantial pollen input through water transport (Whitehead, 1983), whereas wind-transported pollen typically show a low diversity. Sediments of a location proximal to a river delta likely receive a majority of pollen that is water transported, while distal locations are dominated by wind-transported pollen and particularly bisaccate taxa (Hooghiemstra, 1988; Mudie and McCarthy, 1994). To exclude these effects, the percentage of arboreal pollen (AP), representing relative terrestrial temperatures, was calculated excluding bisaccate forms. The nonarboreal pollen (NAP; mainly Poaceae and also Artemisia, Chenopodiaceae, and Asteraceae) consist only of nonaquatic herbs. High AP percentages indicate warm, moist conditions, whereas open vegetation (NAP and Ericaceae) is indicative of cooler, drier conditions consistent with a glacial climate (Faegri et al., 1989). 


\subsection{Palynological processing}

The samples were processed using standard palynological procedures (e.g., Faegri et al., 1989) involving $\mathrm{HCl}(30 \%)$ and cold HF (40\%) digestion of carbonates and silicates. Residues were sieved with $15 \mu \mathrm{m}$ mesh and treated using heavy liquid separation ( $\mathrm{ZnCl}$, specific gravity $2.1 \mathrm{~g} \mathrm{~cm}^{-3}$ ). The slides were counted for dinocysts (with a minimum of 100 cysts) and pollen (with a preferable minimum of 200 grains). The dinocyst taxonomy follows Williams et al. (2017). Resulting counts were expressed as percent abundance of the respective terrestrial or marine groups of palynomorphs.

\subsection{Organic geochemical proxies}

We applied three measures for the relative marine versus terrestrial hydrocarbon sources. The carbon preference index (CPI), based on $\mathrm{C}_{25}-\mathrm{C}_{34}$-alkanes, originally devised to infer thermal maturity (Bray and Evans, 1961), has high values for predominantly terrestrial plant sources (Eglinton and Hamilton, 1967; Rieley et al., 1991). Values closer to 1 indicate greater input from marine microorganisms and/or recycled organic matter (e.g., Kennicutt et al., 1987). Furthermore, peat mosses like Sphagnum are characterized by a dominance of the shorter $\mathrm{C}_{23}$ and $\mathrm{C}_{25} n$-alkanes (e.g., Baas et al., 2000; Vonk and Gustafsson, 2009), whereas longerchain $n$-alkanes $\left(\mathrm{C}_{27}-\mathrm{C}_{33}\right)$ are synthesized by higher plants (e.g., Pancost et al., 2002; Nichols et al., 2006). Here we express the abundance of Sphagnum relative to higher plants as the proportion of $\mathrm{C}_{23}$ and $\mathrm{C}_{25}$ relative to the $\mathrm{C}_{27}-\mathrm{C}_{33}$ odd-carbon-numbered $n$-alkanes. Finally, the input of soil organic matter into the marine environment was estimated using the relative abundance of branched glycerol dialkyl glycerol tetraethers (brGDGTs), produced by bacteria that are abundant in soils, versus that of the marine Thaumarchaeotaderived isoprenoid GDGT crenarchaeol (Sinninghe Damsté et al., 2002), which is quantified in the branched and isoprenoid tetraether (BIT) index (Hopmans et al., 2004). The distribution of brGDGTs in soils is temperature dependent (Weijers et al., 2007; Peterse et al., 2012). Annual mean air temperatures (MATs) were reconstructed based on downcore distributional changes of brGDGT and a global soil calibration that uses both the 5- and 6-methyl isomers of the brGDGTs $\left(\right.$ MAT $_{\mathrm{mr}}$; De Jonge et al., 2014a). Cyclization of branched tetraethers (CBT) ratios was shown earlier to correlate with the ambient MAT and soil pH (Weijers et al., 2007; Peterse et al., 2012). The much improved CBT' ratio (De Jonge et al., 2014a), which includes the pH-dependent 6-methyl brGDGTs, is used here to reconstruct soil $\mathrm{pH}$. The total organic carbon (TOC) and total nitrogen measurements are used to determine the atomic $\mathrm{C} / \mathrm{N}$ ratio that in coastal marine sediments can indicate the dominant source of organic matter, with marine $\mathrm{C} / \mathrm{N}$ values at $\sim 10$ and terrestrial between 15 and 30 (Hedges et al., 1997).

\subsection{Organic geochemical processing}

Organic geochemical analyses were limited to the core and sidewall core samples. For TOC determination $\sim 0.3 \mathrm{~g}$ of freeze-dried and powdered sediment was weighed and treated with $7.5 \mathrm{~mL} 1 \mathrm{M}$ HCL to remove carbonates, followed by $4 \mathrm{~h}$ of shaking, centrifugation, and decanting. This procedure was repeated with $12 \mathrm{~h}$ of shaking. Residues were washed twice with demineralized water and dried at 40$50{ }^{\circ} \mathrm{C}$ for $96 \mathrm{~h}$ after which weight loss was determined. About 15 to $20 \mathrm{mg}$ of ground sample was measured in a Fisons NA 1500 NCS elemental analyzer with a normal Dumas combustion setup. Results were normalized to three external standards (Bureau Communautaire de Référence BCR-71, atropine, and acetanilide) and analyzed before and after the series, and after each 10 measurements. \% TOC was determined by $\% \mathrm{C} x$ decalcified weight divided by the original weight.

For biomarker extraction ca. $10 \mathrm{~g}$ of sediment was freezedried and mechanically powdered. The sediments were extracted with a dichloromethane (DCM) : methanol $(\mathrm{MeOH})$ solvent mixture ( $9: 1, v / v$, three times for 5 min each) using an accelerated solvent extractor (ASE, Dionex 200) at $100^{\circ} \mathrm{C}$ and ca. 1000 psi. The resulting total lipid extract (TLE) was evaporated to near dryness using a rotary evaporator under near vacuum conditions. The TLE was then transferred to a $4 \mathrm{~mL}$ vial and dried under a continuous $\mathrm{N}_{2}$ flow. A $50 \%$ split of the TLE was archived. For the other working half, elemental sulfur was removed by adding activated (in $2 \mathrm{M} \mathrm{HCl}$ ) copper turnings to the TLE in DCM and stirring overnight. The TLE was subsequently filtered over $\mathrm{Na}_{2} \mathrm{SO}_{4}$ to remove the $\mathrm{CuS}$, after which $500 \mathrm{ng}$ of a $\mathrm{C}_{46}$ GDGT internal standard was added (Huguet et al., 2009). The resulting TLE was separated over a small column (Pasteur pipette) packed with activated $\mathrm{Al}_{2} \mathrm{O}_{3}\left(2 \mathrm{~h}\right.$ at $\left.150{ }^{\circ} \mathrm{C}\right)$. The TLE was separated into an apolar, a ketone, and a polar fraction by eluting with $n$-hexane: DCM $9: 1(v / v), n$-hexane: DCM $1: 1$ $(v / v)$, and $\mathrm{DCM}: \mathrm{MeOH} 1: 1(v / v)$ solvent mixtures, respectively. The apolar fraction was analyzed using gas chromatography (GC) coupled to a flame ionization detector (FID) and gas chromatography mass spectroscopy (GC-MS) for quantification and identification of specific biomarkers, respectively. For GC, samples were dissolved in $55 \mu \mathrm{L}$ of hexane and analyzed using a Hewlett-Packard G1513A autosampler interfaced to a Hewlett-Packard 6890 series GC system equipped with a FID, using a CP-Sil 5 fused silica capillary column $(25 \mathrm{~m} \times 0.32 \mathrm{~mm}$, film thickness $0.12 \mu \mathrm{m})$, with a $0.53 \mathrm{~mm}$ pre-column. The temperature program goes from 70 to $130^{\circ} \mathrm{C}(0 \mathrm{~min})$ at $20^{\circ} \mathrm{C} \mathrm{min}^{-1}$ and then to $320^{\circ} \mathrm{C}$ at $4{ }^{\circ} \mathrm{C} \mathrm{min}^{-1}$ (hold time $20 \mathrm{~min}$ ). The injection volume of the samples was $1 \mu \mathrm{L}$.

Analyses of the apolar fractions were performed on a Thermo Finnigan TRACE GC ultra interfaced to a Thermo Finnigan TRACE DSQ MS instrument using the same temperature program, column, and injection volume as for GC 
analysis. Alkane ratios are calculated using peak surface areas of the respective alkanes from the GC-FID chromatograms.

Prior to analyses, the polar fractions, containing the GDGTs, were dissolved in $n$-hexane : propanol $(99: 1, v / v)$ and filtered over a $0.45 \mu \mathrm{m}$ mesh PTFE filter $(\varnothing 4 \mathrm{~mm})$. Subsequently, analyses of the GDGTs were performed using ultra-high-performance liquid chromatography mass spectrometry (UHPLC-MS) on an Agilent 1290 infinity series instrument coupled to a 6130 quadrupole mass selective detector with settings as described in Hopmans et al. (2016). In short, separation of GDGTs was performed on two silica Waters ACQUITY UHPLC HEB HILIC $(1.7 \mu \mathrm{m}$, $2.1 \mathrm{~mm} \times 150 \mathrm{~mm}$ ) columns, preceded by a guard column of the same material. GDGTs were eluted isocratically using $82 \% \mathrm{~A}$ and $18 \% \mathrm{~B}$ for $25 \mathrm{~min}$ and then with a linear gradient to $70 \% \mathrm{~A}$ and $30 \% \mathrm{~B}$ for $25 \mathrm{~min}$, where $\mathrm{A}$ is $n$-hexane and $\mathrm{B}=n$-hexane $:$ isopropanol. The flow rate was constant at $0.2 \mathrm{~mL} \mathrm{~min}^{-1}$. The $[\mathrm{M}+\mathrm{H}]^{+}$ions of the GDGTs were detected in selected ion monitoring mode and quantified relative to the peak area of the $\mathrm{C}_{46}$ GDGT internal standard.

\section{Results}

\subsection{Stable isotope data}

The glacial-interglacial (G-IG) range in Cassidulina teretis $\delta^{18} \mathrm{O}\left(\delta^{18} \mathrm{O}_{\mathrm{b}}\right)$ is $\sim 1 \%$ between MIS 98 and 97 and $\sim 1.3 \%$ o between MIS 95 and 94, but with considerably more variation in especially MIS 95 (Fig. 3). The $\delta^{13} \mathrm{C}_{\mathrm{b}}$ data covary consistently with $\delta^{18} \mathrm{O}_{\mathrm{b}}$ and have a G-IG range of $\sim 1.1 \%$, in addition to one strongly depleted value in MIS $94\left(-3.5 \%\right.$ ). The MIS $95 \delta^{13} \mathrm{C}_{\mathrm{b}}$ values are less variable than the $\delta^{18} \mathrm{O}_{\mathrm{b}}$, pointing to an externally forced signal in the latter. The $\delta^{18} \mathrm{O}_{\mathrm{b}}$ confirms the relation between glacial stages and finely grained sediment as proposed by Kuhlmann et al. (2006a, b). Although the data are somewhat scattered, the A15-3 and A15-4 phase relation to the sediment facies is in agreement with the high-resolution stable isotope benthic foraminifera record of the onshore Noordwijk borehole (Noorbergen et al., 2015). The glacial-to-interglacial ranges are very similar in magnitude with those reported by Sosdian and Rosenthal (2009) for the North Atlantic but are on average lighter by $\sim 0.5 \% \circ\left(\delta^{18} \mathrm{O}_{\mathrm{b}}\right)$ and $\sim 1.8 \%$ o $\left(\delta^{13} \mathrm{C}_{\mathrm{b}}\right)$.

\subsection{Palynology}

Palynomorphs, including dinocysts, freshwater palynomorphs, and pollen, are abundant, diverse, and well preserved in these sediments. Striking is the dominance of conifer pollen. Angiosperm (tree) pollen are present and diverse, but low in abundance relative to conifers. During interglacials (MIS 103, 99, 97, 95, and 93) the pollen record generally shows increased and more diverse tree pollen (particularly Picea and Tsuga) and warm temperate
Osmunda spores, whereas during glacials (MIS 102, (100), 98, 96, and 94) herb and heath pollen indicative of open landscapes are dominant (Fig. S2 in the Supplement). The percentage of arboreal pollen (AP; excluding bisaccate pollen) summarizes these changes, showing maximum values of $>40 \%$ restricted to just a part of the more coarsely grained interglacial intervals (Fig. 3). The percentage record of cold-water dinocysts is quite scattered in some intervals but indicates generally colder conditions within glacial stages and minima during \% AP maxima (Fig. 3). After peak cold conditions and a TOC maximum (see below), but still well within the glacials, the percentage of Protoperidinoid consistently increases. Some intervals (e.g., top of MIS 94) are marked by influxes of freshwater algae (Pediastrum and Botryococcus), indicating a strong riverine input; these data, however, do not indicate a clear trend. This robust in-phase pattern of G-IG variations is also reflected by high $\mathrm{T} / \mathrm{M}$ ratios during glacials, indicating coastal proximity, and low $\mathrm{T} / \mathrm{M}$ during (final phases of) interglacials. The G-IG variability in the $\mathrm{T} / \mathrm{M}$ ratio is superimposed on a long-term increase. The coastal (warm-tolerant) dinocyst maxima are confined to the interglacial intervals and their abundance increases throughout the record. Successive increases in coastal inner neritic Lingulodinium machaerophorum, followed by increases in coastal lagoonal species in the youngest part, mirror the shoaling trend in the $\mathrm{T} / \mathrm{M}$ ratio, which in time corresponds with the gradual progradation of the Eridanos delta front (Fig. S1).

\subsection{Organic geochemical proxies}

The lowest TOC contents are reached in the clay intervals and typically range between $0.5 \%$ in glacials and $1 \%$ in interglacials (Fig. 3). Nitrogen concentrations are relatively stable, resulting in $\mathrm{C} / \mathrm{N}$ ratios primarily determined by organic carbon content, ranging between $\sim 8$ and 9 (glacials) and $\sim 14$ and 17 (interglacials). The carbon preference index (CPI) is generally high, reflecting a continuous input of immature terrestrial organic matter. Minimum CPI values of $\sim 2.8-2.9$ are reached at the transitions from the coarser sediments to the clay intervals, after which they increase to maxima of 4.5-5.0 in the late interglacials. The $n-\mathrm{C}_{23+25}$ Sphagnum biomarker correlates consistently with the $\mathrm{T} / \mathrm{M}$ ratio, $\%$ AP, and cold-water dinocysts (Fig. 3), while the variation in the CPI index is partially out of phase; it is more gradual and lags the \% TOC and other signals. Generally lower BIT index values during interglacials (Fig. 3) indicate more marine conditions, i.e., larger distance to the coast and relatively reduced terrestrial input from the Eridanos catchment (see Sinninghe Damsté, 2016). As both brGDGT input (runoff, soil exposure, and erosion) and sea level (distance to the coast) vary across G-IG timescales, for example during deglaciation and subsequent reactivation of fluvial transport (Bogaart and van Balen, 2000), the variability in the BIT index is somewhat different compared to the $\mathrm{T} / \mathrm{M}$ pa- 


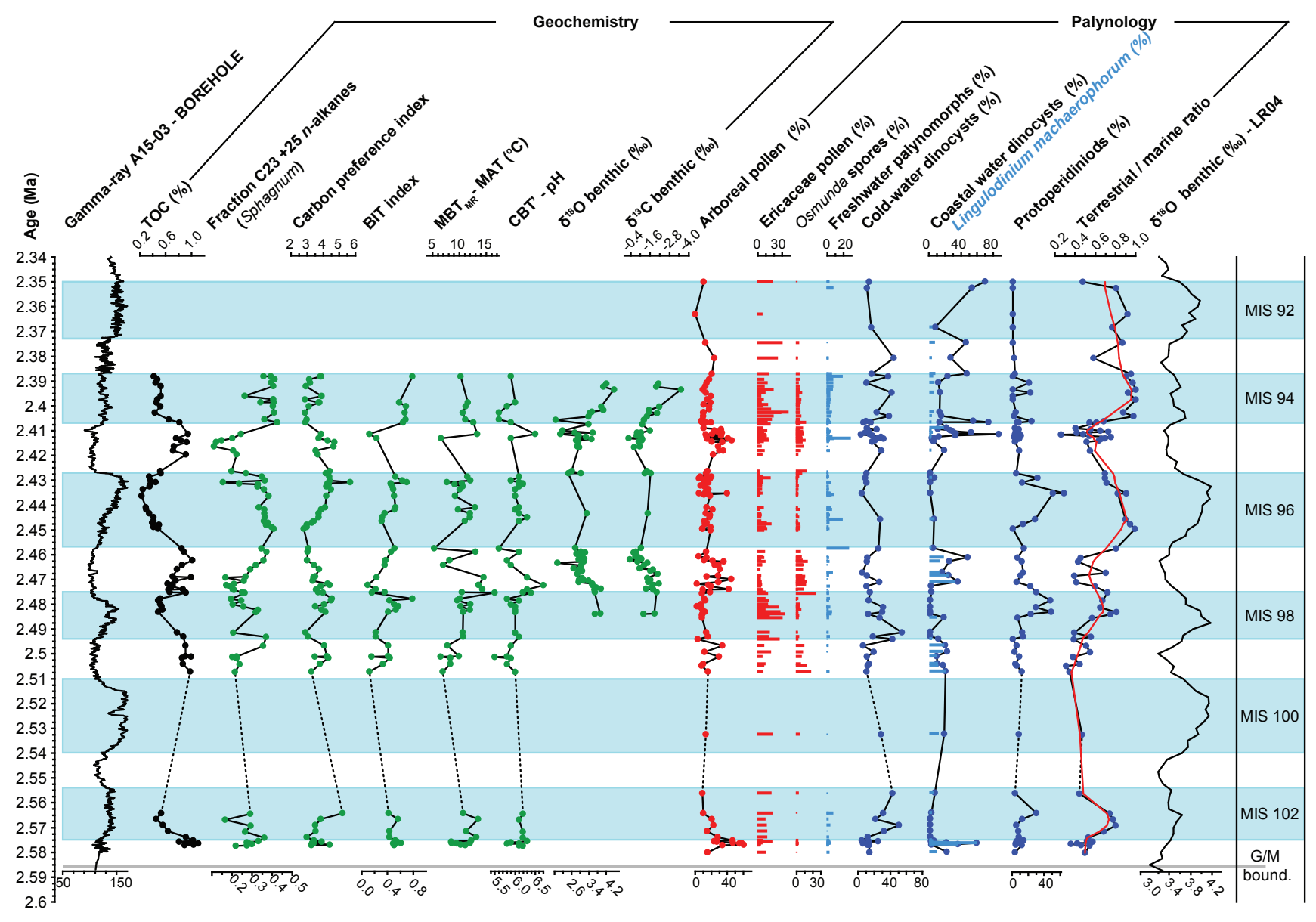

API

Figure 3. Spliced record of A15-3 and A15-4 showing the principal geochemical and palynological indices. Shaded blue intervals represent the identified glacial MIS delimited by the gamma-ray transitions following Kuhlmann et al. (2006a, b). Data density is dependent on type of sample as indicated in Fig. 1. Age scale is based on correlation and LOESS interpolation of the identified MIS transitions to the LR04 benthic stack (Lisiecki and Raymo, 2005) as shown in Fig S3. Data are available in Tables S2 and S3. Red line in the T/M ratio is a LOWESS (locally weighted scatter plot smoothing) function with span 0.1 .

lynomorph ratio (Fig. 3), but is generally in phase with gradual transitions along G-IG cycles. The MAT ${ }_{\mathrm{mr}}$-based temperature reconstructions vary between 5 and $17^{\circ} \mathrm{C}$, reaching maximum values in MIS 97. However, in the MIS $99 / 98$ and MIS 96 / 95 transitions the MAT $_{\mathrm{mr}}$ shows variability opposite to the identified G-IG cycles and the signal contains a lot of high-order variability. Low values during interglacials generally coincide with low CBT'-reconstructed soil $\mathrm{pH}$ of $<6.0$ (Fig. 3).

\section{Discussion}

\subsection{Paleoenvironmental setting and climate signals}

The source area study by Kuhlmann et al. (2004) indicated the Eridanos paleoriver as the principal source of the terrestrial deposits. The detailed seismic interpretations indeed show the advancing Eridanos delta front from the east toward the sites, especially between 2.44 and $2.34 \mathrm{Ma}$ (Fig. S1). This trend is captured by the long-term increases in the $\mathrm{T} / \mathrm{M}$ ratio and the proportion of coastal dinocysts (Fig. 3). Bisaccate pollen is the component most sensitive to differential transport processes, yet regardless of whether it is included in the T / M index (Fig. S5 in the Supplement) the same patterns are recorded, indicating no direct influence of differential transport on the $\mathrm{T} / \mathrm{M}$ ratio in this dataset. During MIS $103,99,97,95$, and 93 the percentage of AP increases indicate generally warmer and more humid conditions than during MIS 102, 98, 96, and 94 (Fig. 3). The cold-water temperature signal based on dinocysts is more variable than the terrestrial cooling signals from the percentage of AP. Pollen assemblages represent mean standing vegetation in the catchment and also depend on dominant circulation patterns and short-term climate variations (Donders et al., 2009). Due to 
exclusion of bisaccate pollen, the percentage of AP is generally low but eliminates any climate signal bias due to the direct effect of sea level changes (Donders et al., 2009; Kotthoff et al., 2014). In the record there are small but significant time lags between proxies, which have important implications for explaining the forcing of G-IG cycles. In the best-constrained MIS transition (98 to 97), the G-IG transition is seen first in decreases of the cold-water dinocysts and $n$ - $\mathrm{C}_{23+25} n$-alkanes predominantly derived from Sphagnum. Subsequently, the BIT decreases, and $\mathrm{MAT}_{\mathrm{mr}}$ and the percentage of AP increase, and finally the $\delta^{18} \mathrm{O}_{\mathrm{b}}$ and $\mathrm{T} / \mathrm{M}$ ratio decrease with a lag of a few thousand years (Fig. 3). Changes in the CPI record are more gradual but are generally in line with $\mathrm{T} / \mathrm{M}$. The percentage of $\mathrm{AP}$ and $\mathrm{T} / \mathrm{M}$ proxies have the most extensive record, and detailed analysis of several G-IG transitions shows that the declines in percentage of AP consistently lead the T/M increases by 3-8 kyr based on the present age model (Fig. S2). The T/M ratio variability corresponds well to the LR04 benthic stack (Fig. 3), which is primarily an obliquity signal. Within the constraints of the sample availability, our record captures the approximate symmetry between glaciation and deglaciation typical of the early Pleistocene (Lisiecki and Raymo, 2005).

The high variability and strongly depleted values in $\delta^{18} \mathrm{O}_{\mathrm{b}}$ during MIS 95 occur during peak coastal dinocyst abundances, suggesting high runoff during maximum warming phases. During cold-water dinocyst maxima, the high abundance of Protoperidinioids indicates high nutrient input and productive spring-summer blooms, which point to strong seasonal temperature variations. This productivity signal markedly weakens in MIS 94 and 92 and the gradual $\mathrm{T} / \mathrm{M}$ increase is consistent with the basin infill and gradually approaching shelf-edge delta (Fig. S1). As Protoperidinioid minima generally occur during TOC maxima there is no indication for a preservation overprint since selective degradation typically lowers relative abundances of these $\mathrm{P}$ cysts (Gray et al., 2017). Combined, the high TOC and CPI values, coastal and stratified water conditions, and intervals of depleted $\delta^{18} \mathrm{O}_{\mathrm{b}}$ document increased Eridanos runoff during interglacials. These suggest a primarily terrestrial organic matter source that, based on mineral provenance studies (Kuhlmann et al., 2004) and high conifer pollen abundance documented here, likely originated from the Fennoscandian Shield. The finely grained material during cold phases is probably transported by meltwater during summer from local glaciers that have developed since the late Pliocene at the surrounding Scandinavian mainland (Mangerud et al., 1996; Kuhlmann et al., 2004).

\subsection{Temperature reconstruction and brGDGT input}

Whereas the BIT index reflects the G-IG cycles consistently, the $\mathrm{MAT}_{\mathrm{mr}}$ record, which is based on GDGTs, has a variable phase relation with the G-IG cycles and high variability. The use of MAT $_{\mathrm{mr}}$ in coastal marine sediments is based on the as- sumption that river-deposited brGDGTs reflect an integrated signal of the catchment area. As the Eridanos system is reactivated following glacials, glacial soils containing brGDGT are likely eroded, causing a mixed signal of glacial and interglacial material. The lowest MAT $_{m r}$ and highest variability is indeed observed during periods of deposition of sediments with a higher TOC content and minima of CBT'-derived $\mathrm{pH}$ below 6 (Fig. 3), consistent with increased erosion of acidic glacial (peat) soil. Additional analysis of the apolar fractions in part of the samples reveals a relatively high abundance of the $\mathrm{C}_{31} 17 \alpha, 21 \beta$-homohopanes during these periods, which in immature soils indicates a significant input of acidic peat (Pancost et al., 2003). This suggests that the variability in the $\mathrm{MAT}_{\mathrm{mr}}$ record is not fully reliable due to (variable) erosion of glacial soils or peats. Alternatively, the terrestrial brGDGT signal may be altered by a contribution of brGDGTs produced in the marine realm. BrGDGTs were initially believed to be solely produced in soils, but emerging evidence suggests that brGDGTs are also produced in the river itself (e.g., Zell et al., 2013; De Jonge et al., 2014b) and in the coastal marine sediments (e.g., Peterse et al., 2009; Sinninghe Damsté, 2016). Based on the modern system, the degree of cyclization of tetramethylated brGDGTs (\#rings tetra $_{\text {) }}$ ) has been proposed to identify a possible in situ overprint (Sinninghe Damsté, 2016). The \#ringstetra in this sediment core is $<0.37$, which is well below the suggested threshold of 0.7 , and thus suggests that the brGDGTs are primarily soil derived. However, a ternary diagram of the brGDGT distribution shows some offset to the global soil calibration that decreases with increasing BIT values (Fig. S6 in the Supplement), pointing to some influence of in situ GDGT production when terrestrial input is relatively low. Finally, selective preservation in the catchment and during fluvial transport may have affected the brGDGT signal, although experimental evidence on fluvial transport processes indicates that these do not significantly affect initial soil-brGDGT compositions (Peterse et al., 2015).

\subsection{Implications for the intensification of Northern Hemisphere glaciations}

The classic Milankovitch model predicts that global ice volume is forced by high northern summer insolation (e.g., Hays et al., 1976). Raymo et al. (2006) suggested an opposite response of ice sheets in both hemispheres due to precession forcing, canceling out the signal and amplifying obliquity in the early Pleistocene. That hypothesis predicts that regional climate records for both hemispheres should contain a precession component that is not visible in the sea level and deep-sea $\delta^{18} \mathrm{O}_{\mathrm{b}}$ record and is supported by evidence from Laurentide Ice Sheet melt and iceberg-rafted debris of the East Antarctic ice sheet (Patterson et al., 2014; Shakun et al., 2016). Alternatively, a dominantly obliquity-forced G-IG cycle is supported by a significant temperature component in the deep-sea $\delta^{18} \mathrm{O}_{\mathrm{b}}$ temperature record (Sosdian and Rosen- 
thal, 2009) and dominant 41 kyr variability in North American biomarker dust fluxes. Our results show that the regional $\mathrm{NH}$ climate on both land and sea surface vary on the same timescale as the local relative sea level, which, with the best possible age information so far (Fig. S3), mirrors the global LR0 $4 \delta^{18} \mathrm{O}_{\mathrm{b}}$ record. The temperature changes lead the local sea level by $3-8 \mathrm{kyr}$, which is consistent with a $\mathrm{NH}$ obliquity forcing scenario as cooling would precede ice buildup and sea level change. Contrary to the model proposed by Raymo et al. (2006), this suggests that the $\mathrm{NH}$ obliquity forcing is the primary driver for the G-IG in the early Pleistocene, although we cannot exclude precession forcing as a contributing factor. Various studies indicate the importance of gradual $\mathrm{CO}_{2}$ decline in the intensification of NHG (Kürschner et al., 1996; Seki et al., 2010; Bartoli et al., 2011) combined with the threshold effects of ice albedo (Lawrence et al., 2010; Etourneau et al., 2010) and land cover changes (Koenig et al., 2011). Simulations of four coupled 3-D ice models indicate that Antarctic ice volume increases respond primarily to sea level lowering, while Eurasian and North American ice sheet growth is initiated by temperature decrease (de Boer et al., 2012). The latter dominate the eustatic sea level variations during glacials. Our observations agree with the modeled temperature sensitivity of $\mathrm{NH}$ ice sheet growth. The dominant obliquity signal further suggests a seasonal aspect of the climate forcing. The combination of high summer productivity, based on increased Protoperidinioid dinocysts, and increased proportions of cold dinocysts during the glacials in the SNS record indicate a strong seasonal cycle. This confirms similar results from the North Atlantic (Hennissen et al., 2015) and is consistent with an obliquity-driven G-IG signal in a midlatitudinal setting, likely promoting meridional humidity transport and ice buildup.

The southward migration of Arctic surface water masses indicated by increases in cold-water dinocysts (Fig. 3) is furthermore relevant for understanding the relation between the Atlantic meridional overturning circulation (AMOC) intensity and ice sheet growth (e.g., Bartoli et al., 2005; Naafs et al., 2010). Mid-Pliocene increased heat transport and subsequent decrease during NHG due to AMOC intensity changes has been invoked from many proxy records but is difficult to sustain in models (Zhang et al., 2013). Our results indicate that the NW European early Pleistocene climate experienced significant cooling in all temperature-sensitive proxies during sea level lowstands, which is consistent with southward displacement of the Arctic front and decreased AMOC (Naafs et al., 2010). The $\mathrm{MAT}_{\mathrm{mr}}$ indicates a $4-6^{\circ} \mathrm{C} \mathrm{G}-$ IG amplitude, although the timing is offset relative to the other proxies. The data-model mismatch in AMOC changes might be due to dynamic feedbacks in vegetation or (sea) ice (Koenig et al., 2011; de Boer et al., 2012) that are prescribed variables in the model comparison by Zhang et al. (2013).

In addition, our SNS record provides a well-dated early Pleistocene G-IG succession integrating marine and terrestrial signals improving on the classic terrestrial Praetiglian stage. While conceptually valid, the earliest Pleistocene glacial stages defined in the continental succession of the SE Netherlands (Van der Vlerk and Florschütz, 1953; Zagwijn, 1960) and currently considered textbook knowledge are highly incomplete and locally varied (Donders et al., 2007). This shallow marine SNS record provides a much more suitable reflection of large-scale transitions and trends in NW Europe and merits further development by complete recovery of the sequence in a scientific drilling project (Westerhoff et al., 2016).

\section{Conclusions}

The independently dated late Pliocene-early Pleistocene sedimentary succession of the southern North Sea Basin provides a record that straddles the intensification of Northern Hemisphere glaciation and the subsequent climate fluctuations in a shallow marine setting in great detail. The intensification of the glaciation and the correlation to Marine Isotope Stages 103 to 92, including the conspicuous first Pleistocene glacial stages 98,96, and 94, is well expressed in the marine and terrestrial palynomorph and organic biomarker records of the southern North Sea. The independent relative sea- and land-based temperature records show clearly coeval (at this resolution) expression of glacial-interglacial and sea level cycles that are well correlated to the LR04 benthic stack. Critically, both the biomarker signals, percentage of AP, and cold-water dinocyst variations show consistent in-phase variability on obliquity timescales, leading sea level changes by 3-8 kyr, which supports a dominantly direct $\mathrm{NH}$ insolation control over early Pleistocene glaciations. Based on this integrated record, $\mathrm{NH}$ obliquity forcing is the primary driver for the glacial-interglacial cycles in the early Pleistocene. Furthermore, our findings support the hypothesis of temperature sensitivity of NH ice sheet growth. The interglacials are characterized by (seasonally) stratified waters and/or nearshore conditions as glacial-interglacial cycles became more expressive and the Eridanos delta progressed into the region. The strong seasonality at midlatitudes points to a vigorous hydrological cycling that should be considered as a potential factor in ice sheet formation in further investigations.

Data availability. All original data of this publication are available in the Supplement Tables S2 and S3.

Supplement. The supplement related to this article is available online at: https://doi.org/10.5194/cp-14-397-2018-supplement.

Author contributions. THD, HB, and GK designed the research. NAGMvH carried out the geochemical analyses under supervision of JWHW, GJR, FP, and JSSD. RV, DM, and THD carried out the palynological analyses and interpreted the data together with FS. 
LL and RPS provided stable isotope data on benthic foraminifera. $\mathrm{JtV}$ provided seismic interpretations. THD integrated the data and wrote the paper with contributions from all authors.

Competing interests. Part of the palynological analyses, aimed construction of a regional stratigraphical model, were financed by Chevron Exploration and Production Netherlands B.V., Total E\&P Nederland B.V., Dana Petroleum Netherlands B.V., Oranje-Nassau Energie B.V., and Energie Beheer Nederland (EBN). The results and conclusions of the present study were by no means influenced by these companies.

Acknowledgements. We are grateful for the constructive comments of Stijn de Schepper and David Naafs and an anonymous referee that helped to improve the paper. We gratefully acknowledge the support in providing the offshore samples to this study and permission to publish from Wintershall Noordzee B.V. and project support from partners Chevron Exploration and Production Netherlands B.V., Total E\&P Nederland B.V., Dana Petroleum Netherlands B.V., Oranje-Nassau Energie B.V., and Energie Beheer Nederland (EBN). Arnold van Dijk is thanked for running $\mathrm{C} / \mathrm{N}$ and stable isotope analyses and Giovanni Dammers for processing palynological samples. The work was partly supported by funding from the Netherlands Earth System Science Center (NESSC) through a gravitation grant (NWO 024.002.001) from the Dutch Ministry for Education, Culture, and Science to Jaap S. Sinninghe Damsté, Gert-Jan Reichart, and Lucas Lourens.

Edited by: Erin McClymont

Reviewed by: Stijn De Schepper, David Naafs,

and one anonymous referee

\section{References}

Baas, M., Pancost, R., van Geel, B., and Sinninghe Damsté, J. S.: A comparative study of lipids in Sphagnum species, Org. Geochem., 31, 535-539, https://doi.org/10.1016/S01466380(00)00037-1, 2000.

Bakken, K. and Dale, B.: Dinoflagellate cysts in Upper Quaternary sediments from southwestern Norway and potential correlations with the oceanic record, Boreas, 15, 185-190, https://doi.org/10.1111/j.1502-3885.1986.tb00082.x, 1986.

Bartoli, G., Sarnthein, M., and Weinelt, M.: Final closure of Panama and the onset of Northern Hemisphere glaciation, Earth Planet. Sc. Lett., 237, 33-44, https://doi.org/10.1016/j.eps1.2005.06.020, 2005.

Bartoli, G., Hönisch, B., and Zeebe, R. E.: Atmospheric $\mathrm{CO}_{2}$ decline during the Pliocene intensification of Northern Hemisphere glaciations, Paleoceanography, 26, PA4213, https://doi.org/10.1029/2010PA002055, 2011.

Bijlsma, S.: Fluvial sedimentation from the Fennoscandian area into the Northwest European Basin during the Late Cenozoic, Geol. Mijnbouw, 60, 337-345, 1981.

Bogaart, P. W. and van Balen, R. T.: Numerical modeling of the response of alluvial rivers to Quaternary climate change, Global
Planet. Change, 27, 147-163, https://doi.org/10.1016/S09218181(01)00064-9, 2000.

Bray, E. E. and Evans, E. D.: Distribution of n-parrafins as a clue to recognition of source beds, Geochim. Cosmochim. Ac., 22, 2-15, https://doi.org/10.1016/0016-7037(61)90069-2, 1961.

Brierley, C. M. and Fedorov, A. V.: Relative importance of meridional and zonal sea surface temperature gradients for the onset of the ice ages and Pliocene - Pleistocene climate evolution, Paleoceanography, 25, PA2214, https://doi.org/10.1029/2009PA001809, 2010.

Brigham-Grette, J., Melles, M., Minyuk, P. S., Andreev, A. A., Tarasov, P. E., DeConto, R. M., König, S., Nowaczyk, N. R., Wennrich, V., Rosén, P., Haltia-Hovi, E., Cook, T. L., Gebhardt, C., Meyer-Jacob, C., Snyder, J. A., and Herzschuh, U.: Pliocene warmth, polar amplification, and stepped Pleistocene cooling recorded in NE Arctic Russia, Science, 340, 1421-1427, https://doi.org/10.1126/science.1233137, 2013.

Caston, V. N. D.: The Quaternary sediments of the North Sea, in: The north-west European shelf seas: the sea bed and the sea in motion, I, Geology and Sedimentology, edited by: Banner, F. T., Collins, M. B., and Massie, K. S., Elsev. Oceanogr. Serie., 24A, 195-270, 1979.

Dale, B.: Dinoflagellate cyst ecology: modelling and geological applications, in: Palynology: Principles and Application, Vol. 3, edited by: Jansonius, J. and McGregor, D. C., American Association of Stratigraphic Palynologists Foundation, College Station, Texas, USA, 1249-1275, 1996.

de Boer, B., van de Wal, R. S. W., Lourens, L. J., Bintanja, R., and Reerink, T. J.: A continuous simulation of global ice volume over the past 1 million years with 3-D ice-sheet models, Clim. Dynam., 41, 1365, https://doi.org/10.1007/s00382-012-1562-2, 2012.

de Haas, H., Boer, W., and van Weering, T. C. E.: Recent sediment and organic carbon burial in a shelf sea; the North Sea, Mar. Geol., 144, 131-146, https://doi.org/10.1016/S00253227(97)00082-0, 1997.

De Jonge, C., Hopmans, A. C, Zell, C. I., Kim, J.-H., Schouten, S., and Sinninghe Damsté, J. S.: Occurrence and abundance of 6-methyl branched glycerol dialkyl glycerol tetraethers in soils: Implications for palaeoclimate reconstruction, Geochim. Cosmochim. Ac., 141, 97-112, https://doi.org/10.1016/j.gca.2014.06.013, 2014a.

De Jonge, C., Stadnitskaia, A., Hopmans, E. C., Cherkashov, G., Fedotov, A., and Sinninghe Damsté, J. S.: In-situ produced branched glycerol dialkyl glycerol tetraethers in suspended particulate matter from the Yenisei River, Eastern Siberia, Geochim. Cosmochim. Ac., 125, 476-491, https://doi.org/10.1016/j.gca.2014.06.013, 2014b.

De Schepper, S., Fischer, E. I., Groeneveld, J., Head, M. J., and Matthiessen, J.: Deciphering the palaeoecology of Late Pliocene and Early Pleistocene dinoflagellate cysts, Palaeogeogr. Palaeocl., 309, 17-32, https://doi.org/10.1016/j.palaeo.2011.04.020, 2011.

De Schepper, S., Groeneveld, J., Naafs, B. D. A., Van Renterghem, C., Hennissen, J., Head, M. J., Louwye, S., and Fabian, K.: Northern Hemisphere glaciation during the globally warm early Late Pliocene, Plos One, 8, e81508, https://doi.org/10.1371/journal.pone.0081508, 2013. 
de Vernal, A.: Marine palynology and its use for studying nearshore environments, From Deep-Sea to Coastal Zones: Methods - Techniques for Studying Paleoenvironments, IOP Conference Series: Earth and Environmental Science, 5, 012002, https://doi.org/10.1088/1755-1307/5/1/012002, 2009.

Donders, T. H., Kloosterboer-van Hoeve, M. L., Westerhoff, W., Verreussel, R. H. C. M., and Lotter, A. F.: Late Neogene continental stages in NW Europe revisited, Earth-Sci. Rev., 85, 161186, https://doi.org/10.1016/j.earscirev.2007.06.004, 2007.

Donders, T. H., Weijers, J. W. H., Munsterman, D. K., Kloosterboervan Hoeve, M. L., Buckles, L. K., Pancost, R. D., Schouten, S., Sinninghe Damsté, J. S., and Brinkhuis, H.: Strong climate coupling of terrestrial and marine environments in the Miocene of northwest Europe, Earth Planet. Sc. Lett., 281, 215-225, https://doi.org/10.1016/j.epsl.2009.02.034, 2009.

Eglinton, G. and Hamilton, R. J.: Leaf epicuticular waxes, Science, 156, 1322-1335, https://doi.org/10.1126/science.156.3780.1322, 1967.

Etourneau, J., Schneider, R., Blanz, T., and Martinez, P.: Intensification of the Walker and Hadley atmospheric circulations during the Pliocene-Pleistocene climate transition, Earth Planet. Sc. Lett., 297, 103-110, https://doi.org/10.1016/j.epsl.2010.06.010, 2010.

Faegri, K., Iversen, J., Kaland, P. E., and Krzywinski, K.: Text book of pollen analysis, IV Edition, The Blackburn Press, New Jersey, USA, 328 pp., 1989.

Gibbard P. L. and Lewin, J.: Filling the North Sea Basin: Cenozoic sediment sources and river styles, Geol. Belg., 19, 201-217, https://doi.org/10.20341/gb.2015.017, 2016.

Gray, D. D., Zonneveld, K. A., and Versteegh, G. J.: Species-specific sensitivity of dinoflagellate cysts to aerobic degradation: A five-year natural exposure experiment, Rev. Palaeobot. Palyno., 247, 175-187, https://doi.org/10.1016/j.revpalbo.2017.09.002, 2017.

Haug, G. H. and Tiedemann, R.: Effect of the formation of the Isthmus of Panama on Atlantic Ocean thermohaline circulation, Nature, 393, 673-676, https://doi.org/10.1038/31447, 1998.

Haug, G. H., Sigman, D. M., Tiedemann, R., Pedersen, T. F., and Sarnthein, M.: Onset of permanent stratification in the subarctic Pacific Ocean, Nature, 40, 779-782, https://doi.org/10.1038/44550, 1999.

Haug, G. H., Ganopolski, A., Sigman, D. M., Rosell-Mele, A., Swann, G. E. A, Tiedemann, R., Jaccard, S. L., Bollmann, J., Maslin, M. A., Leng, M. J., and Eglinton, G.: North Pacific seasonality and the glaciation of North America 2.7 million years ago, Nature, 433, 821-825, https://doi.org/10.1038/nature03332, 2005.

Hays, J. D., Imbrie, J., and Shackleton, N. J.: Variations in the Earth's orbit: pacemaker of the ice ages, Science, 194, 11211132, https://doi.org/10.1126/science.194.4270.1121, 1976.

Head, M. J.: Modern dinoflagellate cysts and their biological affinities, in: Palynology: Principles and Application, Vol. 3, edited by: Jansonius, J. and McGregor, D. C., American Association of Stratigraphic Palynologists Foundation, College Station, Texas, USA, 1197-1248, 1996.

Head, M. J., Riding, J. B., Eidvin, T., and Chadwick, R. A.: Palynological and foraminiferal biostratigraphy of (Upper Pliocene) Nordland Group mudstones at Sleip- ner, northern North Sea, Mar. Petrol. Geol., 21, 277-297, https://doi.org/10.1016/j.marpetgeo.2003.12.002, 2004.

Hedges, J. I., Keil, R. G., and Benner, R.: What happens to terrestrial organic matter in the ocean?, Org. Geochem., 27, 195-212, https://doi.org/10.1016/S0146-6380(97)00066-1, 1997.

Hennissen, J. A. I., Head, M. J., De Schepper, S., and Groeneveld, J.: Increased seasonality during the intensification of Northern Hemisphere glaciation at the Pliocene-Pleistocene transition $\sim 2.6 \mathrm{Ma}$, Quaternary Sci. Rev., 129, 321-332, https://doi.org/10.1016/j.quascirev.2015.10.010, 2015.

Hennissen, J. A. I., Head, M. J., De Schepper, S., and Groeneveld, J.: Dinoflagellate cyst paleoecology during the Pliocene-Pleistocene climatic transition in the North Atlantic, Palaeogeogr. Palaeocl., 470, 81-108, https://doi.org/10.1016/j.palaeo.2016.12.023, 2017.

Heusser, L. E. and Shackleton, N. J.: Direct marinecontinental correlation: 150,000-year oxygen isotope-pollen record from the North Pacific, Science, 204, 837-839, https://doi.org/10.1126/science.204.4395.837, 1979.

Hooghiemstra, H.: Palynological records from Northwest African marine sediments: a general outline of the interpretation of the pollen signal, Philos. T. Roy. Soc. B, 318, 431-449, https://doi.org/10.1098/rstb.1988.0018, 1988.

Hooghiemstra, H. and Ran, E. T. H.: Late Pliocene-Pleistocene high resolution pollen sequence of Colombia: An overview of climatic change, Quatern. Int., 21, 63-80, 1994.

Hopmans, E. C., Weijers, J. W. H., Schefuss, E., Herfort, L., Sinninghe Damsté, J. S., and Schouten, S.: A novel proxy for terrestrial organic matter in sediments based on branched and isoprenoid tetraether lipids, Earth Planet. Sc. Lett., 24, 107-116, https://doi.org/10.1016/j.epsl.2004.05.012, 2004.

Hopmans, E. C., Schouten, S., and Sinninghe Damsté, J. S.: The effect of improved chromatography on GDGT-based palaeoproxies, Org. Geochem., 93, 1-6, https://doi.org/10.1016/j.orggeochem.2015.12.006, 2016.

Huguet, C., Hopmans, E. C., Febo-Ayala, W., Thompson, D. H., Sinninghe Damsté, J. S., and Schouten, S.: An improved method to determine the absolute abundance of glycerol dibiphytanyl glycerol tetraether lipids, Org. Geochem., 37, 1036-1041, https://doi.org/10.1016/j.orggeochem.2009.09.003, 2009.

Huuse, M., Lykke-Andersen, H., and Michelsen, O.: Cenozoic evolution of the eastern North Sea Basin - new evidence from highresolution and conventional seismic data, Marine Geology, 177, 243-269, 2001.

Huybers, P.: Combined obliquity and precession pacing of late Pleistocene deglaciations, Nature, 480, 229-232, https://doi.org/10.1038/nature10626, 2011.

Keigwin, L. D.: Isotope paleoceanography of the Caribbean and east Pacific: role of Panama uplift in late Neogene time, Science, 217, 350-353, https://doi.org/10.1126/science.217.4557.350, 1982.

Kemna, H. A. and Westerhoff, W. E.: Remarks on the palynologybased chronostratigraphic subdivision of the Pliocene terrestrial deposits in NW-Europe, Quatern. Int., 164-165, 184-196, https://doi.org/10.1016/j.quaint.2006.10.017, 2007.

Kennicutt II, M. C., Barker, C., Brooks, J. M., DeFreitas, D. A., and Zhu, G. H.: Selected organic matter source indicators in the Orinoco, Nile and Changiiang deltas, Org. Geochem., 11, 41-51, https://doi.org/10.1016/0146-6380(87)90050-7, 1987. 
Knies, J., Cabedo-Sanz, P., Belt, S. T., Baranwal, S., Fietz, S., and Rosell-Mele, A.: The emergence of modern sea ice cover in the Arctic Ocean, Nat. Commun., 5, 5608, https://doi.org/10.1038/ncomms6608, 2014.

Koenig, S. J., DeConto, R. M., and Pollard, D.: Late Pliocene to Pleistocene sensitivity of the Greenland Ice Sheet in response to external forcing and internal feedbacks, Clim. Dynam., 37, 1247, https://doi.org/10.1007/s00382-011-1050-0, 2011.

Kotthoff, U., Greenwood, D. R., McCarthy, F. M. G., MúllerNavarra, K., Prader, S., and Hesselbo, S. P.: Late Eocene to middle Miocene (33 to 13 million years ago) vegetation and climate development on the North American Atlantic Coastal Plain (IODP Expedition 313, Site M0027), Clim. Past, 10, 1523-1539, https://doi.org/10.5194/cp-10-1523-2014, 2014.

Kuhlmann, G. and Wong, T. E.: Pliocene paleoenvironment evolution as interpreted from 3D-seismic data in the southern North Sea, Dutch offshore sector, Mar. Petrol. Geol., 25, 173-189, https://doi.org/10.1016/j.marpetgeo.2007.05.009, 2008.

Kuhlmann, G., Pedersen, R.-B., de Boer, P., and Wong, T. E.: Provenance of Pliocene sediments and paleoenvironmental change in the southern North Sea region using $\mathrm{Sm} / \mathrm{Nd}$ (samarium-neodymium) provenance ages and clay mineralogy, Sediment. Geol., 171, 205-226, https://doi.org/10.1016/j.sedgeo.2004.05.016, 2004.

Kuhlmann, G., Langereis, C. G., Munsterman, D., van Leeuwen, R.-J., Verreussel, R., Meulenkamp, J., and Wong, T. E.: Chronostratigraphy of Late Neogene sediments in the southern North Sea Basin and paleoenvironmental interpretations, Palaeogeogr. Palaeocl., 239, 426-455, https://doi.org/10.1016/j.palaeo.2006.02.004, 2006a.

Kuhlmann, G., Langereis, C. G., Munsterman, D., van Leeuwen, R.-J., Verreussel, R., Meulenkamp, J. E., and Wong, Th. E.: Integrated chronostratigraphy of the Pliocene-Pleistocene interval and its relation to the regional stratigraphical stages in the southern North Sea region, Neth. J. Geosci., 85, 19-35, https://doi.org/10.1017/S0016774600021405, 2006b.

Kürschner, W. A., van der Burgh, J., Visscher, H., and Dilcher, D. L.: Oak leaves as biosensors of late Neogene and early Pleistocene paleoatmospheric $\mathrm{CO}_{2}$ concentrations, Mar. Micropaleonto., 27, 299-312, https://doi.org/10.1016/03778398(95)00067-4, 1996.

Larsson, L. M., Dybkjaer, K., Rasmussen, E. S., Piasecki, S., Utescher, T., and Vajda, V.: Miocene climate evolution of northern Europe: A palynological investigation from Denmark, Palaeogeogr. Palaeocl., 309, 161-175, https://doi.org/10.1016/j.palaeo.2011.05.003, 2011.

Lawrence, K. T., Sosdian, S., White, H. E., and Rosenthal, Y.: North Atlantic climate evolution through the Plio-Pleistocene climate transitions, Earth Planet. Sc. Lett., 300, 329-342, https://doi.org/10.1016/j.epsl.2010.10.013, 2010.

Lisiecki, L. E. and Raymo, M. E.: A Pliocene-Pleistocene stack of 57 globally distributed benthic $\delta^{18} \mathrm{O}$ records, Paleoceanography, 20, PA1003, https://doi.org/10.1029/2004PA001071, 2005.

Lister, A. M.: The impact of Quaternary Ice Ages on mammalian evolution, Philos. T. Roy. Soc. B, 359, 221-241, https://doi.org/10.1098/rstb.2003.1436, 2004.

Mackensen, A. and Hald, M.: Cassidulina teretis Tappan and C. laevigata d'Orbigny: their modern and late Quaternary distribution in northern seas, J. Foramin. Res., 18, 16-24, https://doi.org/10.2113/gsjfr.18.1.16, 1988.

Mangerud, J., Jansen, E., and Landvik, J.: Late Cenozoic history of the Scandinavian and Barents Sea ice sheets, Global Planet. Change, 12, 11-26, https://doi.org/10.1016/09218181(95)00009-7, 1996.

Maslin, M. A., Li, X. S., Loutre, M. F., and Berger A.: The contribution of orbital forcing to the progressive intensification of Northern Hemisphere Glaciation, Quaternary Sci. Rev., 17, 411426, https://doi.org/10.1016/S0277-3791(97)00047-4, 1998.

McCarthy, F. M. G. and Mudie, P.: Oceanic pollen transport and pollen: dinocyst ratios as markers of late Cenozoic sea level change and sediment transport, Palaeogeogr. Palaeocl., 138, 187-206, https://doi.org/10.1016/S0031-0182(97)00135-1, 1998.

Meijer, T., Cleveringa, P., Munsterman, D. K., and Verreussel, R. M. C. H.: The Early Pleistocene Praetiglian and Ludhamian pollen stages in the North Sea Basin and their relationship to the marine isotope record, J. Quaternary Sci., 21, 307-310, https://doi.org/10.1002/jqs.956, 2006.

Meloro, C., Raia, P., Carotenuto, F., and Barbera, C.: Diversity and turnover of Plio-Pleistocene large mammal fauna from the Italian Peninsula, Palaeogeogr. Palaeocl., 268, 58-64, https://doi.org/10.1016/j.palaeo.2008.08.002, 2008.

Michelsen, O., Thomsen, E., Danielsen, M., Heilmann-Clausen, C., Jordt, H., and Laursen, G.-V.: Cenozoic sequence stratigraphy in eastern North Sea, in: Mesozoic and Cenozoic sequence stratigraphy of European Basins, edited by: de Graciansky, P.-C., Jacquin, T., Vail, P. R., and Farley, M. B., Sepm. Spec. P., 60, 91-118, https://doi.org/10.2110/pec.98.02.0091, 1998.

Mudelsee, M. and Raymo, M. E.: Slow dynamics of the Northern Hemisphere glaciation, Paleoceanography, 20, PA4022, https://doi.org/10.1029/2005PA001153, 2005.

Mudie, P. J. and McCarthy, F. M. G.: Late Quaternary pollen transport processes, western North Atlantic: Data from box models, cross-margin and N-S transects, Mar. Geol., 118, 79-105, https://doi.org/10.1016/0025-3227(94)90114-7, 1994.

Naafs, B. D. A., Stein, R., Hefter, J., Khelifi, N., De Schepper, S., and Haug, G. H.: Late Pliocene changes in the North Atlantic current, Earth Planet. Sc. Lett., 298, 434-442, https://doi.org/10.1016/j.eps1.2010.08.023, 2010.

Naafs, B. D. A., Hefter, J., Acton, G., Haug, G. H., Martínez-Garcia, A., Pancost, R., and Stein, R.: Strengthening of North American dust sources during the late Pliocene (2.7 Ma), Earth Planet. Sc. Lett., 317-318, 8-19, https://doi.org/10.1016/j.eps1.2011.11.026, 2012.

Naafs, B. D. A., Hefter, J., and Stein, R.: Millennial-scale ice rafting events and Hudson Strait Heinrich(-like) Events during the late Pliocene and Pleistocene, a review, Quaternary Sci. Rev., 80, 128, https://doi.org/10.1016/j.quascirev.2013.08.014, 2013.

Nichols, J. E., Booth, R. K., Jackson, S. T., Pendall, E. G., and Huang, Y.: Paleohydrologic reconstruction based on n-alkane distributions in ombrotrophic peat, Org. Geochem., 37, 15051513, https://doi.org/10.1016/j.orggeochem.2006.06.020, 2006.

Noorbergen, L. J., Lourens, L. J., Munsterman, D. K., and Verreussel, R. M. C. H.: Stable isotope stratigraphy of the early Quaternary of borehole Noordwijk, southern North Sea, Quatern. Int., 386, 148-157, https://doi.org/10.1016/j.quaint.2015.02.045, 2015. 
Overeem, I., Weltje, G. J., Bishop-Kay, C., and Kroonenberg, S. B.: The Late Cenozoic Eridanos delta system in the Southern North Sea Basin: a climate signal in sediment supply?, Basin Res., 13, 293-312, https://doi.org/10.1046/j.1365-2117.2001.00151.x, 2001.

Pagani, M., Liu, Z., LaRiviere, J., and Ravelo, A. C.: High Earth-system climate sensitivity determined from Pliocene carbon dioxide concentrations, Nat. Geosci., 3, 27-30, https://doi.org/10.1038/NGEO724, 2010.

Pancost, R. D., Baas, M., van Geel, B., and Sinninghe Damsté, J. S.: Biomarkers as proxies for plant inputs to peats: an example from a sub-boreal ombrotrophic bog, Org. Geochem., 33, 675690, 2002.

Pancost, R. D., Baas, M., van Geel, B., and Sinninghe Damsté, J. S.: Response of an ombrotrophic bog to a regional climate event revealed by macrofossil, molecular and carbon isotopic data, The Holocene, 13, 921-932, https://doi.org/10.1016/S01466380(02)00048-7, 2003.

Patterson, M. O., McKay, R., Naish, T., Escutia, C., JimenezEspejo, F. J., Raymo, M. E., Meyers, S. R., Tauxe, L., Brinkhuis, H., and IODP Expedition 318 Scientists: Orbital forcing of the East Antarctic ice sheet during the Pliocene and Early Pleistocene, Nat. Geosci., 7, 841, https://doi.org/10.1038/ngeo2273, 2014.

Peterse, F., Kim, J.-H., Schouten, S., Kristensen, D. K., Koç, N., and Sinninghe Damsté, J. S.: Constraints on the application of the MBT / CBT palaeothermometer at high latitude environments (Svalbard, Norway), Org. Geochem., 40, 692-699, https://doi.org/10.1016/j.orggeochem.2009.03.004, 2009.

Peterse, F., van der Meer, J., Schouten, S., Weijers, J. W. H., and Fierer, N.: Revised calibration of the MBT-CBT paleotemperature proxy based on branched tetraether membrane lipids in surface soils, Geochim. Cosmochim. Ac., 96, 215-229, https://doi.org/10.1016/j.gca.2012.08.011, 2012.

Peterse, F., Moy, C. M., and Eglinton, T. I.: A laboratory experiment on the behaviour of soil-derived core and intact polar GDGTs in aquatic environments, Biogeosciences, 12, 933-943, https://doi.org/10.5194/bg-12-933-2015, 2015.

Poore, H. R., Samworth, R., White, N. J., Jones, S. M., and McCave, I. N.: Neogene overflow of Northern Component Water at the Greenland-Scotland Ridge, Geoch. Geophy. Geosy., 7, Q06010, https://doi.org/10.1029/2005gc001085, 2006.

Pross, J. and Brinkhuis, H.: Organic-walled dinoflagellate cysts as paleoenvironmental indicators in the Paleogene; a synopsis of concepts, Paläontologische Zeitschrift, 79, 53-59, 2005.

Quaijtaal, W., Donders, T. H., Persico, D., and Louwye, S.: Characterising the middle Miocene Mi-events in the Eastern North Atlantic realm - A first high-resolution marine palynological record from the Porcupine Basin, Palaeogeogr. Palaeocl., 399, 140-159, https://doi.org/10.1016/j.palaeo.2014.02.017, 2014.

Ravelo, A. C.: Palaeoclimate: Warmth and glaciation, Nature Geoscience, 3, 672-674, https://doi.org/10.1038/ngeo965, 2010.

Ravelo, A. C., Andreasen, D. H., Lyle, M., Lyle, A. O., and Wara, M. W.: Regional climate shifts caused by gradual global cooling in the Pliocene epoch, Nature, 429, 263-267, https://doi.org/10.1038/nature02567, 2004.

Raymo, M. E.: The initiation of Northern Hemisphere glaciation, Annu. Rev. Earth Pl. Sc., 22, 353-383, https://doi.org/10.1146/annurev.ea.22.050194.002033, 1994.
Raymo, M. E., Ruddiman, W. F., Backman, J., Clement, B. M., and Martinson, D. G.: Late Pliocene variation in Northern Hemisphere ice sheets and North Atlantic Deep Water circulation, Paleoceanography, 4, 413-446, https://doi.org/10.1029/PA004i004p00413, 1989.

Raymo, M. E., Lisiecki, L., and Nisancioglu, K.: Plio-Pleistocene ice volume, Antarctic climate, and the global $\delta^{18} \mathrm{O}$ record, Science, 313, 492-495, https://doi.org/10.1126/science.1123296, 2006.

Reichart, G. J. and Brinkhuis, H.: Late Quaternary Protoperidinium cysts as indicators of paleoproductivity in the northern Arabian Sea, Mar. Micropaleontol., 49, 303-315, https://doi.org/10.1016/S0377-8398(03)00050-1, 2003.

Rieley, G., Collier, R. J., Jones, D. M., and Eglinton, G.: The biogeochemistry of Ellesmere Lake, U.K., I: source correlation of leaf wax inputs to the sedimentary lipid record, Org. Geochem., 17, 901-912, https://doi.org/10.1016/01466380(91)90031-E, 1991.

Rochon, A., de Vernal, A., Turon, J. L., Mathiessen, J., and Head, M. J.: Distribution of recent dinoflagellate cysts in surface sediments from the North Atlantic Ocean and adjacent seas in relation to sea-surface parameters: American Association of Stratigraphic Palynologists Foundation Contributions Series, 35, 150 pp., 1999.

Rosoff, D. B. and Corliss, B. H.: An analysis of Recent deep-sea benthic foraminiferal morphotypes from the Norwegian and Greenland seas, Palaeogeogr. Palaeocl., 91, 13-20, https://doi.org/10.1016/0031-0182(92)90028-4, 1992.

Ruddiman, W. F., Raymo, M., and McIntyre, A.: Matuyama 41,000-year cycles: North Atlantic Ocean and northern hemisphere ice sheets, Earth Planet. Sc. Lett., 80, 117-129, https://doi.org/10.1016/0012-821X(86)90024-5, 1986.

Sangiorgi, F. and Donders, T. H.: Reconstructing 150 years of eutrophication in the north-western Adriatic Sea (Italy) using dinoflagellate cysts, pollen and spores, Estuar. Coast Shelf S., 60, 69-79, https://doi.org/10.1016/j.ecss.2003.12.001, 2004.

Schreck, M., Meheust, M., Stein, R., and Matthiessen, J.: Response of marine palynomorphs to Neogene climate cooling in the Iceland Sea (ODP Hole 907A), Mar. Micropaleontol., 101, 49-67, https://doi.org/10.1016/j.marmicro.2013.03.003, 2013.

Seki, O., Foster, G. L., Schmidt, D. N., Mackensen, A., Kawamura, K., Pancost, R. D.: Alkenone and boron-based Pliocene $p \mathrm{CO}_{2}$ records, Earth Planet. Sc. Lett., 292, 201-211, https://doi.org/10.1016/j.epsl.2010.01.037, 2010.

Shackleton, N. J. and Hall, M. A.: Oxygen and carbon isotope stratigraphy of Deep Sea Drilling Project Hole 552A: Plio- Pleistocene glacial history, in: Initial Reports of the Deep Sea Drilling Project, edited by: Roberts, D. G., Schnittker, D., Backman, J., Baldauf, J. G., Desprairies, A., Homrighausen, R., Huddlestun, P., Kaltenback, A. J., Krumsiek, K. A. O., Morton, A. C., Murray, J. W., Westberg-Smith, J., and Zimmerman, H. B., 81, 599-609, U.S. Govt. Printing Office, Washington, 1984.

Shakun, J. D., Raymo, M. E., and Lea, D. W.: An early Pleistocene $\mathrm{Mg} / \mathrm{Ca}-\delta^{18} \mathrm{O}$ record from the Gulf of Mexico: Evaluating ice sheet size and pacing in the 41-kyr world, Paleoceanography, 31, 1011-1027, https://doi.org/10.1002/2016PA002956, 2016.

Sinninghe Damsté, J. S.: Spatial heterogeneity of sources of branched tetraethers in shelf systems - The geochemistry of tetraethers in the Berau River delta (Kaliman- 
tan, Indonesia), Geochim. Cosmochim. Ac., 186, 13-31, https://doi.org/10.1016/j.gca.2016.04.033, 2016.

Sinninghe Damsté, J. S., Schouten, S., Hopmans, E. C., van Duin, A. C. T., and Geenevasen, J. A. J.: Crenarchaeol: the characteristic core glycerol dibiphytanyl glycerol tetraether membrane lipid of cosmopolitan pelagic crenarchaeota, J. Lipid. Res., 43, 16411651, https://doi.org/10.1194/jlr.M200148-JLR200, 2002.

Sluijs, A., Pross, J., and Brinkhuis, H.: From greenhouse to icehouse; organic-walled dinoflagellate cysts as paleoenvironmental indicators in the Paleogene, Earth Science Reviews, 68, 281-315, https://doi.org/10.1016/j.earscirev.2004.06.001, 2005.

Sørensen, J. C., Gregersen, U., Breiner, M., and Michelsen, O.: High-frequency sequence stratigraphy of Upper Cenozoic deposits in the central and southeastern North Sea areas, Mar. Petrol. Geol., 14, 99-123, https://doi.org/10.1016/S02648172(96)00052-9, 1997.

Sosdian, S. and Rosenthal, Y.: Deep-sea temperature and ice volume changes across the Pliocene-Pleistocene climate transitions, Science, 325, 306-310, https://doi.org/10.1126/science.1169938, 2009.

Svenning, J.-C.: Deterministic Plio-Pleistocene extinctions in the European cool-temperate tree flora, Ecol. Lett., 6, 646-653, https://doi.org/10.1046/j.1461-0248.2003.00477.x, 2003.

Tabor, C. R., Poulsen, C. J., and Pollard, D.: Mending Milankovitch's theory: obliquity amplification by surface feedbacks, Clim. Past, 10, 41-50, https://doi.org/10.5194/cp-10-412014, 2014.

Ten Veen, J. H., Verweij, J. M., De Bruin, G., and Donders, T. H.: First steps toward maturing the shallow gas play - Results of an integrated exploration workflow, Proceedings of the International Petroleum Technology Conference 2014, Doha, Qatar, 1922 January 2014, Society of Petroleum Engineers, 2960-2967, https://doi.org/10.2523/IPTC-17563-MS, 2014.

Thöle, H., Gaedicke, C., Kuhlmann, G., and Reinhardt, L.: Late Cenozoic sedimentary evolution of the German North Sea - A seismic stratigraphic approach, Newsl. Stratigr., 47, 299-329, https://doi.org/10.1127/0078-0421/2014/0049, 2014.

Tzedakis, P. C., Crucifix, M., Mitsui, T., and Wolff, E. W.: A simple rule to determine which insolation cycles lead to interglacials, Nature, 542, 427-432, https://doi.org/10.1038/nature21364, 2017.

Van der Vlerk, I. M. and Florschütz, F.: The palaeontological base of the subdivision of the Pleistocene in the Netherlands, Verhandelingen Koninklijke Nederlandse Akademie van Wetenschappen, Afdeling Natuurkunde, 1e Reeks XX, 2, 1-58, 1953.

Versteegh, G. J. M. and Zonneveld, K. A. F.: Determination of (palaeo-)ecological preferences of dinoflagellates by applying detrended and canonical correspondence analysis to late Pliocene dinoflagellate cyst assemblages of the south Italian Singa section, Rev. Palaeobot. Palyno., 84, 181-199, https://doi.org/10.1016/0034-6667(94)90050-7, 1994.

Vonk, J. E. and Gustafsson, Ö: Calibrating $n$-alkane Sphagnum proxies in sub-Arctic Scandinavia, Org. Geochem., 40, 10851090, https://doi.org/10.1016/j.orggeochem.2009.07.002, 2009.

Weijers, J. W. H., Schouten, S., Van den Donker, J. C., Hopmans, E. C., and Sinninghe Damsté, J. S.: Environmental controls on bacterial tetraether membrane lipid distribution in soils, Geochim. Cosmochim. Ac., 71, 703-713, https://doi.org/10.1016/j.gca.2006.10.003, 2007.
Westerhoff, W., Donders, T., and Luthi, S.: Report on ICDP workshop CONOSC (COring the NOrth Sea Cenozoic), Sci. Dril., 21, 47-51, https://doi.org/10.5194/sd-21-47-2016, 2016.

Whitehead, D. R.: Wind pollination: some ecological and evolutionary perspectives, in: Pollination Biology, edited by: Real, L., Academic Press, Orlando, California, 97-108, 1983.

Williams, G. L., Fensome, R. A., and MacRae, R. A.: The Lentin and Williams index of fossil dinoflagellates 2004 edition, 97108, American Association of Stratigraphic Palynologists, Contributions Series 48, College Station, Texas, USA, 1097 pp., 2017.

Zagwijn, W. H.: Aspects of the Pliocene and early Pleistocene vegetation in The Netherlands, Mededelingen van de Geologische Stichting, Serie C III-1-5, 1-78, 1960.

Zagwijn, W. H.: The beginning of the Ice Age in Europe and its major subdivisions, Quaternary. Sci. Rev., 11, 583-591, https://doi.org/10.1016/0277-3791(92)90015-Z, 1992.

Zell, C., Kim, J.-H., Moreira-Turcq, P., Abril, G., Hopmans, E. C., Bonnet, M.-P., Sobrinho, R. L., and Sinninghe Damsté, J. S.: Disentangling the origins of branched tetraether lipids and crenarchaeol in the lower Amazon River: implications for GDGT-based proxies, Limnol. Oceanogr., 58, 343-353, https://doi.org/10.4319/lo.2013.58.1.0343, 2013.

Zhang, Z.-S., Nisancioglu, K. H., Chandler, M. A., Haywood, A. M., Otto-Bliesner, B. L., Ramstein, G., Stepanek, C., Abe-Ouchi, A., Chan, W.-L., Bragg, F. J., Contoux, C., Dolan, A. M., Hill, D. J., Jost, A., Kamae, Y., Lohmann, G., Lunt, D. J., Rosenbloom, N. A., Sohl, L. E., and Ueda, H.: Mid-pliocene Atlantic Meridional Overturning Circulation not unlike modern, Clim. Past, 9, 1495-1504, https://doi.org/10.5194/cp-9-1495-2013, 2013.

Ziegler, P. A.: Geological Atlas of Western and Central Europe (2nd edition), Shell Internationale Petroleum Maatschappij B. V., Geological Society Publishing House, Bath, 239 pp., 1990.

Zöllmer, V. and Irion, G.: Tonminerale des Nordseeraumes ihr Verteilungsmuster in kreidezeitlichen bis pleistozänen Sedimentabfolgen und in den Oberflächensedimenten der heutigen Nordsee: Courier Forschungsinstitut Senckenberg, 190, Frankfurt am Main, 72 pp., 1996.

Zonneveld, K. A. F., Chen, L., Möbius, J., and Mahmoud, M. S.: Environmental significance of dinoflagellate cysts from the proximal part of the Po-river discharge plume (off southern Italy, Eastern Mediterranean), J. Sea. Res., 62, 189-213, https://doi.org/10.1016/j.seares.2009.02.003, 2009.

Zonneveld, K. A. F., Marret, F., Versteegh, G. J. M., Bogus, K., Bonnet, S., Bouimetarhan, I., Crouch, E., de Vernal, A., Elshanawany, R., Edwards, L., Esper, O., Forke, S., Grøsfjeld, K., Henry, M., Holzwarth, U., Kielt, J.-F., Kim, S.Y., Ladouceur, S., Ledu, D., Chen, L., Limoges, A., Londeix, L., Lu, S.-H., Mahmoud, M. S., Marino, G., Matsouka, K., Matthiessen, J., Mildenhal, D. C., Mudie, P., Neil, H. L., Pospelova, V., Qi, Y., Radi, T., Richerol, T., Rochon, A., Sangiorgi, F., Solignac, S., Turon, J.-L., Verleye, T., Wang, Y., and Young, M.: Atlas of modern dinoflagellate cyst distribution based on 2405 data points, Rev. Palaeobot. Palyno., 191, 1-197, https://doi.org/10.1016/j.revpalbo.2012.08.003, 2013. 